\title{
The $\beta$-subunit of human chorionic gonadotrophin exists as a homodimer
}

\section{S A Butler ${ }^{1}$, P Laidler ${ }^{2}$, J R Porter ${ }^{1}$, A T Kicman ${ }^{2}$, T Chard ${ }^{1}$, D A Cowan ${ }^{2}$ and R K Iles ${ }^{1}$}

${ }^{1}$ Williamson Laboratory, Department of Obstetrics and Gynaecology, St Bartholomew's and the Royal London School of Medicine and Dentistry, London, UK

${ }^{2}$ Drug Control Centre, King's College London, Manresa Road, London SW3 6LX, UK

(Requests for offprints should be addressed to P Laidler, Drug Control Centre, King's College London, Manresa Road, London SW3 6LX, UK or R K Iles, Williamson Laboratory,

East Wing, St Bartholomew's Hospital, West Smithfield, London EC1A 7BE, UK)

\begin{abstract}
The free $\beta$-subunit of human chorionic gonadotrophin (hCG $\beta$ ) is well recognised as a product of many epithelial tumours. Recently, it has been shown that this ectopic production may have a functional relationship to tumour growth. The growth-promoting activity of hCG $\beta$ may be explained by its structural similarity to a family of growth factors which all contain the same distinct topological fold known as the cystine-knot motif. Since the other members of this family all exhibit their activities as homo- and heterodimers, it is possible that the same may be true for hCG $\beta$.

Using size-exclusion chromatography, low stringency SDS-PAGE and matrix assisted laser desorption/ionisation (MALDI) time-of-flight (TOF) mass spectrometry (MS) we have shown that pure preparations of hCG $\beta$ contain hCG $\beta \beta$ homodimers. Size-exclusion chromatography revealed asymmetric
\end{abstract}

elution profiles with a forward peak corresponding to the size-exclusion characteristic of a globular protein with an approximate mass of $44-54 \mathrm{kDa}$ and a late shoulder centered around an elution position expected for a globular protein of approximately $29 \mathrm{kDa}$. Two immunoreactive hCG $\beta$ species, of approximately 32 and $64 \mathrm{kDa}$, were clearly resolved by SDS-PAGE and Western blotting. When analysed by MALDI-TOF MS a $\sim 23 \mathrm{kDa}$ monomer and a $\sim 46 \mathrm{kDa}$ dimer were identified.

Formation of hCG $\beta \beta$ homodimers is consistent with the behaviour of other cystine-knot growth factors and strengthens the inclusion of the glycoprotein hormones within this superfamily. It has yet to be determined whether it is this dimeric molecular species that is responsible for growth-promoting activity of hCG $\beta$ preparations in tumours.

Fournal of Molecular Endocrinology (1999) 22, 185-192

\section{INTRODUCTION}

Human chorionic gonadotrophin (hCG) is a member of the glycoprotein hormone family, which also includes luteinising hormone (LH), folliclestimulating hormone and thyroid-stimulating hormone, all existing as $\alpha \beta$ heterodimers. The $\alpha$ subunit is common to all members of the group and it is the $\beta$-subunits which confer the structural and functional identity of the heterodimer. Furthermore, only the intact heterodimer is functional; the free subunits do not exhibit gonadotrophic or thyrotrophic activity. Therefore, any growth factor activity exhibited by the free $\beta$-subunit is generally regarded not to occur through the $\mathrm{LH} / \mathrm{hCG}$ receptor, but via a novel pathway.
The free $\beta$-subunit of $\mathrm{hCG}(\mathrm{hCG} \beta$ ) is widely used as a marker of Down's syndrome (Spencer et al. 1992, Cuckle et al. 1994) and has been proposed as a prognostic marker for many epithelial tumours (Iles et al. 1996). In both situations the expression of hCG $\beta$ was regarded as having no biological significance. However, it has now been shown that the $\beta$-subunit may have its own unique functions. Lunardi-Iskandar et al. (1995) and Gillott et al. (1996) have shown growth inhibitory and growth stimulatory effects respectively of free hCG $\beta$. Recently, elucidation of the crystal structure of hCG revealed a similar topology between hCG $\beta$ and transforming growth factor $\beta$ (TGF $\beta$ ), platelet derived growth factor $\beta$ (PDGF $\beta$ ) and nerve cell growth factor (NGF) (Lapthorn et al. 1994, Wu 
et al. 1994). The feature common to all four molecules is a unique group of three disulphide bridges in the centre of the molecule, the so called 'cystine-knot motif'. It is interesting to note that the cystine-knot growth factors mediate their biological activity through the formation of homo- and/or heterodimers. In view of the recently reported biological activity of hCG $\beta$ (Gillott et al. 1996) and the structural similarities within this group of proteins, we have investigated the possible existence of an hCG $\beta \beta$ homodimer using size-exclusion chromatography, SDS-PAGE and matrix-assisted laser desorption/ionisation (MALDI) time-of-flight (TOF) mass spectrometry (MS).

\section{MATERIALS AND METHODS}

Recombinant hCG $\beta$ subunit, which is expressed in a mammalian cell line, containing $\mathrm{N}$ - and $\mathrm{O}$-linked carbohydrate moieties similar to those in authentic hCG $\beta$, was purchased from Sigma Chemical Co. (Poole, Dorset, UK). The international reference preparation of free hCG $\beta$, CR123, which is derived from splitting intact heterodimeric $\mathrm{hCG}$ isolated from pregnancy urine, was a kind gift from Dr Steven Birken (Columbia University, New York, USA) (Storring et al. 1980). MALDI matrices $\alpha$-cyano-4-hydroxycinnamic acid (CHCA), 2,5dihydroxybenzoic acid (DHB), 3,5-dimethoxy-4hydroxybenzoic acid (sinapinic acid (SA)) and 5-methoxysalicylic acid (MSA) were purchased from Aldrich Chemical Co. (Gillingham, Dorset, UK) and used without further purification.

\section{Size-exclusion gel chromatography}

Recombinant hCG $\beta$ and CR123 preparation hCG $\beta$ $(100 \mu \mathrm{l}$ at $50 \mu \mathrm{g} / \mathrm{ml}$ in $1 \% \mathrm{w} / \mathrm{v}$ BSA-PBS) were loaded onto a column $(630 \mathrm{~mm} \times 10 \mathrm{~mm}$ internal diameter) of Sephacryl S200HR via a Rheodyne (Berkeley, CA, USA) injection loop. The samples were then eluted with $0 \cdot 1 \mathrm{M}$ ammonium bicarbonate buffer $(\mathrm{pH} \mathrm{7.4)}$ by ascending flow at a rate of $0.3 \mathrm{ml} / \mathrm{min}$ using a Shimadzu (Kyoto, Japan) LC-6A HPLC pump. Eluted fractions $(0.9 \mathrm{ml})$ were collected into polystyrene tubes containing $100 \mu \mathrm{l}$ $10 \% \mathrm{w} / \mathrm{v}$ BSA-PBS. Buffer containing BSA was added to the collection tubes and at injection, in order to reduce the non-specific absorption of the proteins of interest to the column components and fraction vessels.

The column was calibrated using gel-exclusion chromatography globular protein markers (Sigma): Blue dextran (700 kDa - void volume), alcohol dehydrogenase $(150 \mathrm{kDa}), \quad \mathrm{BSA} \quad(66 \mathrm{kDa})$ and carbonic anhydrase $(29 \mathrm{kDa})$.

\section{Assay for hCG $\beta$}

Fractions eluting from the size-exclusion column were assayed for total hCG $\beta$ using an in-house polyclonal RIA. This assay has been described by Iles (1991) and uses a polyclonal antiserum, S424, raised against the $\beta$-subunit of $\mathrm{hCG}$, as binder and ${ }^{125}$ I-labelled CR123 free hCG $\beta$ as tracer. This assay recognises the $\beta$-subunit of hCG in the heterodimer of intact $\mathrm{hCG}$, as the free subunit and the hCG $\beta$ degradation product $\beta$-core.

\section{SDS PAGE and Western blotting}

Electrophoresis was essentially carried out by the method described by Laemmli (1970). Recombinant hCG $\beta$ samples were separated on 10\% acrylamide gels under both reducing and low stringency conditions using the Mighty Small II gel system (Hoefer, Amersham Pharmacia Biotech, St Albans, Herts, UK). Ten-microlitre samples of the recombinant hCG $\beta$ preparation $(100 \mu \mathrm{g} / \mathrm{ml})$ were combined with an equivolume of either non-reducing sample buffer (125 mM Tris-HCl, pH 6.8, 20\% glycerol, $4 \%$ SDS, $0 \cdot 02 \%$ bromophenol blue) or reducing sample buffer (containing 10\% $\beta$ mercaptoethanol) before separation. The reducing sample was additionally heated for $3 \mathrm{~min}$ in a boiling water bath to ensure complete reduction of the thiol moieties; the low stringency sample was not heated. In both cases ${ }^{14} \mathrm{C}$-labelled Rainbow Molecular Mass Markers (Amersham Pharmacia Biotech) were subjected to the same conditions as the corresponding sample prior to separation. The separated proteins were transferred to polyvinylidene difluoride nylon membrane (Immobilon-P, Millipore, Sigma) using the Biometra Fastblot B32 semi-dry blotter (Anachem-Scotlab, Luton, Beds, UK), blocked, then probed overnight with monoclonal anti-hCG $\beta$ 1/07 (Quantum Biosystems Ltd, Cambridge, Cambs, UK) labelled with ${ }^{125} \mathrm{I}$ by the chloramine-T method of Greenwood et al. (1963). Following multiple washes with PBS 0.1\% Tween 20 (Sigma) the blot was exposed to Kodak X-OMAT AR imaging film and developed using the Kodak M35 X-OMAT processor (Kodak, Hemel Hempstead, Herts, UK).

\section{MALDI-TOF MS}

The matrices selected for this work are used widely in MALDI analysis, SA and a 9:1 (w/w) mixture of DHB with MSA, referred to as super-DHB 
(sDHB), being particularly useful for the analysis of glycoproteins (Kussmann et al. 1997). In addition, CHCA was chosen because relative to $\mathrm{SA}$ or $\mathrm{sDHB}$ it has a lower proton affinity (Burton et al. 1997) and is therefore more liable to favour dissociation of non-covalent complexes. Matrix solutions were prepared using HPLC grade acetonitrile (Fisher Scientific UK Ltd, Loughborough, Leics, UK) and purified water (Elgastat UHQ, High Wycombe, Bucks, UK). Solutions of $\mathrm{SA}$ and $\mathrm{CHCA}$ were prepared at $10 \mathrm{~g} / 1$ in acetonitrile/water $(70: 30, \mathrm{v} / \mathrm{v})$. sDHB (a 9:1 (w/w) mixture of DHB with MSA) (Karas et al. 1993), was prepared at a concentration of $20 \mathrm{~g} / 1$ in acetonitrile/water $(30: 70, \mathrm{v} / \mathrm{v})$. Recombinant hCG $\beta$ and the international reference preparation were prepared to concentrations of $0 \cdot 8$ and $0.4 \mathrm{mg} / \mathrm{ml}$ respectively in purified water.

Half-microlitre aliquots of hCG $\beta$ sample were mixed on the MALDI sample support with 0.5-1 $\mu$ l matrix solution and allowed to air dry. Spectra were then generated using a LASERMAT 2000 mass spectrometer (Thermo Bioanalysis Ltd, Hemel Hempstead, Herts, UK). Light from a pulsed nitrogen laser $(\lambda \max =337 \mathrm{~nm})$ was used to desorb ions from the samples and they were accelerated down a $0.5 \mathrm{~m}$ drift tube and detected by a micro-channel plate detector. The detector signal was digitised at a sampling rate of $500 \mathrm{MHz}$ and transferred to a personal computer for data analysis. Spectra were generated by summing 20-35 laser shots and were calibrated externally using horse heart cytochrome C (12 360 Da) (Sigma).

\section{RESULTS}

\section{Size-exclusion chromatography}

The chromatogram of recombinant hCG $\beta$ revealed an asymmetric elution profile of immunoreactive material consisting of a forward peak eluting at a position corresponding to the Stokes' radius of a globular protein of approximately $44 \mathrm{kDa}$ in mass and a late shoulder approximating to a globular protein of $29 \mathrm{kDa}$. CR123 $\beta$ eluted in a similar manner with a forward peak of $\sim 44-54 \mathrm{kDa}$ and a late shoulder of $\sim 29 \mathrm{kDa}$ (Fig. 1).

\section{SDS PAGE and Western blotting}

Under low stringency (non-reducing) conditions two protein bands were separated by SDS-PAGE and following Western blotting were identified immunologically as hCG $\beta$. The band with the higher molecular mass (hCG $\beta$ dimer) was exactly double $(\sim 64 \mathrm{kDa})$ that of the lower band corresponding to hCG $\beta$ monomer $(\sim 32 \mathrm{kDa})$.

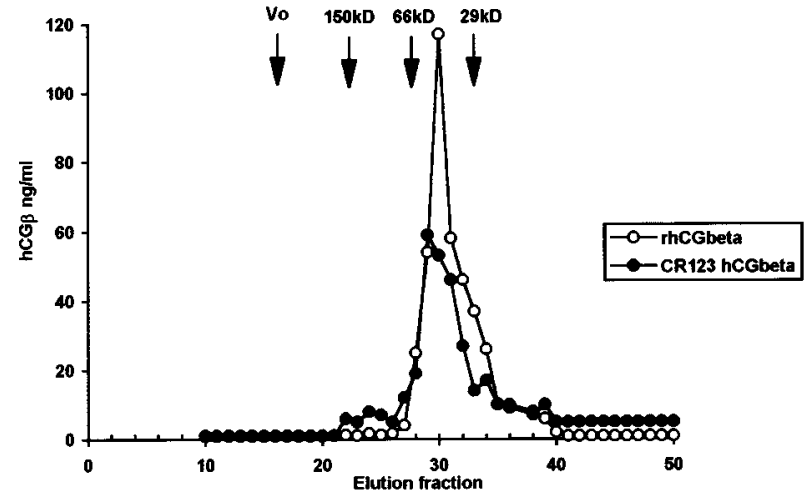

FIGURE 1. Sephacryl S200HR size-exclusion chromatography elution profiles of recombinant and CR123 hCG $\beta$ preparations. Arrows mark the elution maxima of gel-exclusion chromatography globular protein markers: alcohol dehydrogenase $(150 \mathrm{kDa}), \mathrm{BSA}$ $(66 \mathrm{kDa})$ and carbonic anhydrase $(29 \mathrm{kDa})$. Void volume (Vo) was determined as the elusion maxima for Blue dextran $(\sim 700 \mathrm{kDa})$.

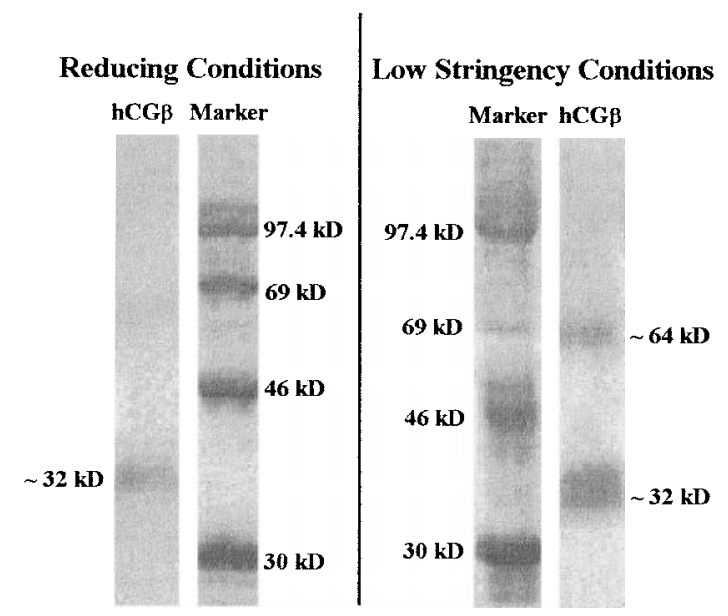

FIGURE 2. Scanned autoradiograph showing a Western blot of separated recombinant hCG $\beta$ under reducing and low stringency conditions, probed with

${ }^{125}$ I-anti-hCG $\beta$ monoclonal antibody $1 / 07$.

Under reducing conditions the same hCG $\beta$ preparation gave rise to only one band corresponding to hCG $\beta$ monomer (32 kDa) (Fig. 2).

\section{MALDI-TOF MS}

MALDI-TOF mass spectra of recombinant hCG $\beta$ analysed in $\mathrm{SA}, \mathrm{sDHB}$ and $\mathrm{CHCA}$ matrices are shown in Figs 3, 4 and 5 respectively. All the spectra were characterised by peaks corresponding to the singly $(\mathrm{m} / \mathrm{z} \sim 23 \mathrm{kDa})$ and doubly $(\mathrm{m} / \mathrm{z}$ $\sim 11.5 \mathrm{kDa}$ ) charged ions of hCG $\beta$. Spectra generated in sDHB and SA also contain a peak at $\mathrm{m} / \mathrm{z}$ 


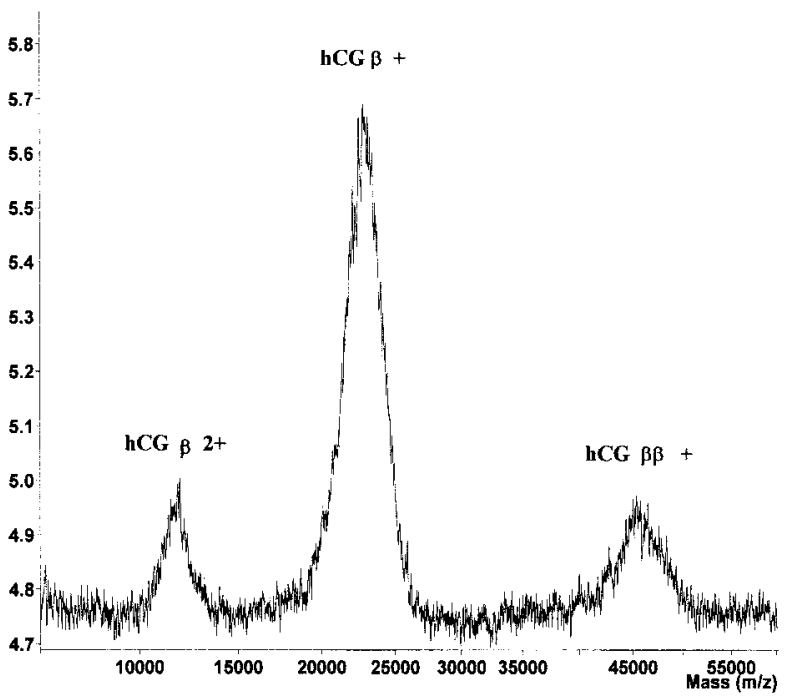

FIGURE 3. MALDI-TOF mass spectrum of recombinant hCG $\beta(0.4 \mathrm{mg} / \mathrm{ml}) 0.5 \mu \mathrm{l}$ with $0.5 \mu \mathrm{l} \mathrm{SA}$ $10 \mathrm{~g} / \mathrm{l}$ in acetonitrile/water (70:30), showing peaks corresponding to monomeric doubly charged hCG $\beta$ $(\beta 2+)$, monomeric hCG $\beta(\beta+)$ and dimeric $\mathrm{hCG} \beta(\beta \beta+)$ at approximately $11 \cdot 5,23$ and $46 \mathrm{kDa}$ respectively.

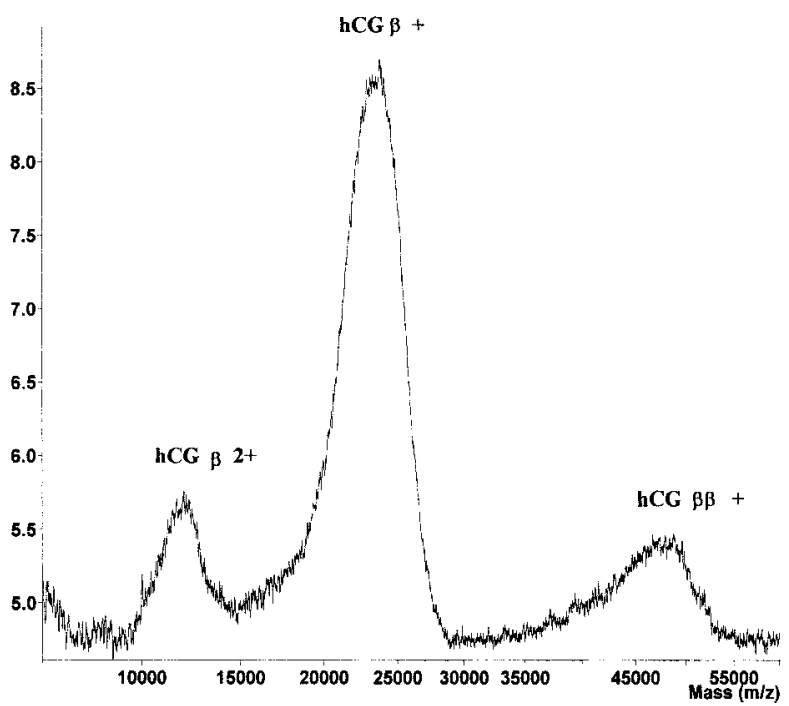

FIGURE 4. MALDI-TOF mass spectrum of recombinant hCG $\beta(0.8 \mathrm{mg} / \mathrm{ml}) 0.5 \mu \mathrm{l}$ with $1 \mu \mathrm{sDHB}$ $20 \mathrm{~g} / \mathrm{l}$ in acetonitrile/water (30:70), showing peaks corresponding to monomeric doubly charged hCG $\beta$ $(\beta 2+)$, monomeric hCG $\beta(\beta+)$ and dimeric hCG $\beta(\beta \beta+)$ at approximately $11 \cdot 5,23$ and $46 \mathrm{kDa}$ respectively.

$\sim 46 \mathrm{kDa}$ indicating the presence of a dimer of hCG $\beta$. This peak was absent from the spectra acquired using $\mathrm{CHCA}$ as the matrix. The signal due to the doubly charged monomer was considerably more intense when CHCA was used as the matrix.

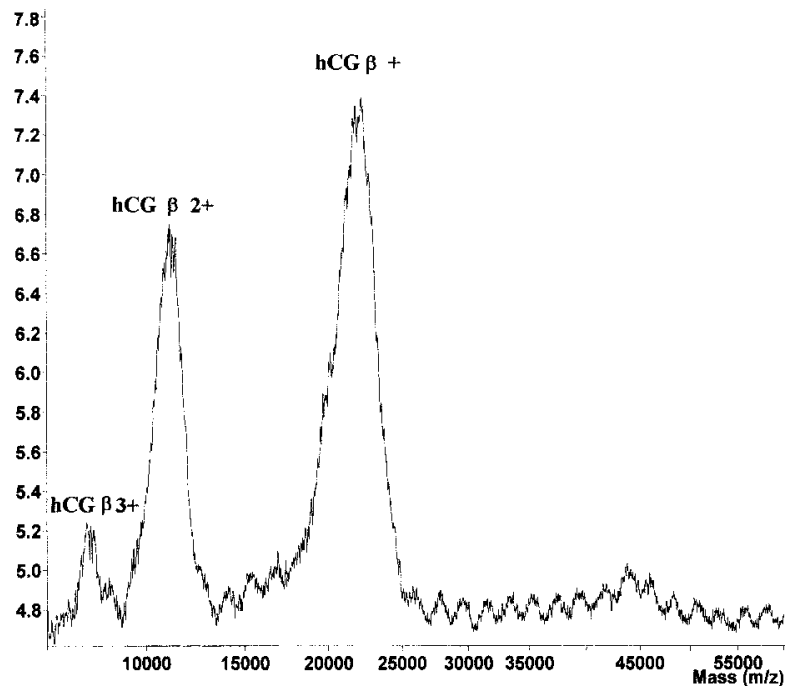

FIGURE 5. MALDI-TOF mass spectrum of recombinant hCG $\beta(0.8 \mathrm{mg} / \mathrm{ml}) 0 \cdot 5 \mu \mathrm{l}$ with $0.5 \mu \mathrm{l} \mathrm{CHCA}$ $10 \mathrm{~g} / \mathrm{l}$ in acetonitrile/water (70:30), showing peaks corresponding to monomeric trebly charged hCG $\beta$ $(\beta 3+)$, monomeric doubly charged hCG $\beta(\beta 2+)$, and monomeric hCG $\beta(\beta+)$ at approximately $7 \cdot 7,11 \cdot 5$ and $23 \mathrm{kDa}$ respectively.

In addition, an ion corresponding to the trebly charged hCG $\beta$ monomer was present in the $\mathrm{CHCA}$ spectra. Peaks corresponding to the singly and doubly charged ions of hCG $\beta$ were observed in the spectrum of the international reference preparation for hCG $\beta$ (CR123 $\beta$ ) analysed in SA. The singly charged ion of an hCG $\beta \beta$ homodimer was also present, albeit at low intensity (Fig. 6). The microheterogeneous nature of $\mathrm{hCG} \beta$, due primarily to variations in glycosylation, and in particular sialic acid content, results in the broad peaks characteristic of the generated spectra.

\section{DISCUSSION}

The ectopic production of free $\mathrm{hCG} \beta$ is a well-recognised phenomenon in many epithelial tumours (Iles et al. 1990). Expression of hCG $\beta$ by these cancers was originally thought to carry no biological significance, but it is now apparent that this event may significantly affect tumour development given the growth effects described recently (Gillott et al. 1996). Similarly hCG $\beta$ has also been shown to induce regression in the AIDS-related tumour Kaposi's sarcoma (Lunardi-Iskandar et al. 1995 ) and several studies on both in vitro and in vivo models report similar findings (Harris 1995, Gill et al. 1996). However, opinions differ as to the 


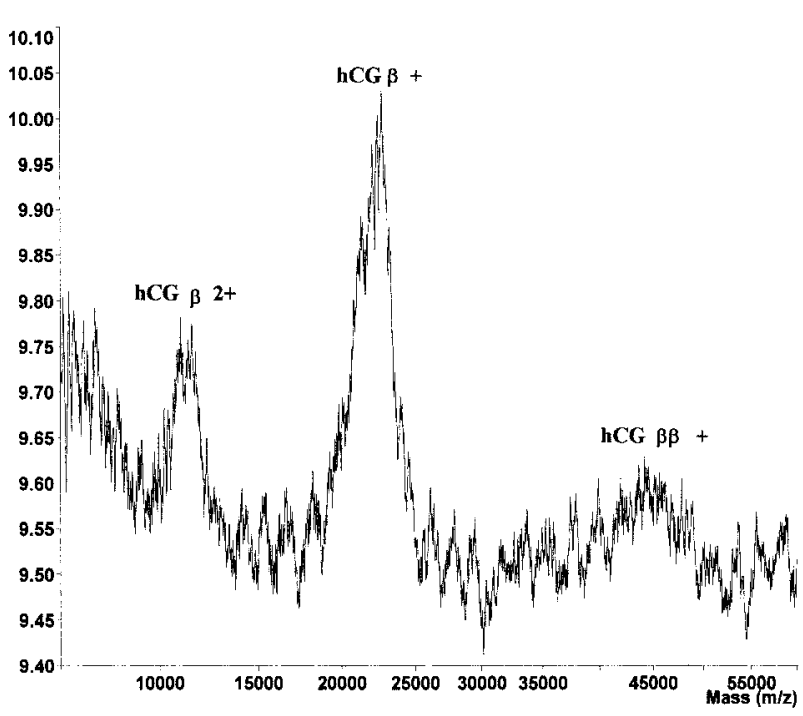

FIGURE 6. MALDI-TOF mass spectrum of CR123 $\beta$ $(0.4 \mathrm{mg} / \mathrm{ml}) 0.5 \mu \mathrm{l}$ with $0.5 \mu \mathrm{l} \mathrm{SA}$ (acetonitrile/water), showing peaks corresponding to monomeric doubly charged hCG $\beta(\beta 2+)$, monomeric hCG $\beta(\beta+)$ and dimeric hCG $\beta(\beta \beta+)$ at approximately $11 \cdot 5,23$ and $46 \mathrm{kDa}$ respectively.

identity of the actual functional component(s) in the preparations used in these studies; intact $\mathrm{hCG}$ (Harris 1995), hCG $\beta$ (Lunardi-Iskander et al. 1995), $\beta$-core (Kachra et al. 1997), the carboxyterminal peptide of hCG $\beta$ (Albini et al. 1997) and an hCG associated factor, HAF (Lunardi-Iskandar et al. 1998), which may be a ribonuclease inhibitor (Griffiths et al. 1997), have all been proposed as the active molecule.

The individual $\alpha$ - and $\beta$-subunits of hCG share a distinctive topological folding pattern, known as the cystine-knot motif, with the growth factors TGF $\beta$, NGF and PDGF $\beta$ (Murray-Rust et al. 1993, Sun \& Davies 1995). Although all these growth factors bind to quite different receptor families, biological activity is achieved only through the formation of either hetero- and/or homodimers. TGF $\beta$ signalling in particular requires a $\beta \beta$ homodimer and PDGF $\beta$ forms $\beta \beta$ homodimers which initiate second messenger phosphorylation; PDGF $\beta \alpha$ heterodimers and PDGFa homodimers are also known to initiate and control kinase activity (Heath 1993). The TGF and PDGF $\beta \beta$ homodimers are bound together 'top to tail' to yield the structure required for receptor binding and activation. This subunit association is very similar to that seen within the hCG heterodimer, in which the carboxy-terminal sequence of the $\beta$-subunit wraps around the $\alpha$-subunit in a 'seatbelt' arrangement (Lapthorn et al. 1994). These structural similarities, together with the recently described growth-promoting activity of hCG $\beta$ (Gillott et al. 1996), suggest that the action may be brought about by an hCG $\beta \beta$ homodimer. It is notable that homodimers of the $\alpha$ - and $\beta$-subunits of bovine LH have also been reported (Peng et al. 1997).

Furthermore it has been indicated that in high concentrations, $\beta$-core, a breakdown product of $\mathrm{hCG}$ and hCG $\beta$, can also form homodimers (Iles 1991). In view of the very similar folding patterns of hCG $\beta$ and these growth factors, a possible candidate to mediate the growth factor activities of $\mathrm{hCG} \beta$ is a putative $\mathrm{hCG} \beta \beta$ homodimer. Since free $\mathrm{hCG} \beta$ is unable to activate the $\mathrm{LH} / \mathrm{hCG}$ receptor and stimulate secondary messengers, the reported growth factor activities are assumed to proceed via novel, and as yet unidentified, pathways.

Our data support the existence of $\mathrm{hCG} \beta \beta$ homodimers in preparations of $\mathrm{hCG} \beta$ which have previously been shown to exhibit growth factor activities. Intact $\mathrm{hCG}$ and free $\mathrm{hCG} \beta$ have always been found to behave unusually on size-exclusion chromatography, eluting close to the void volume and at the expected position of human serum albumin $(\sim 70 \mathrm{kDa})$ on Sephadex G-100 sizeexclusion columns (Bell et al. 1969, Canfield et al. 1971). This phenomenon is due to the extensive glycosylation of $\mathrm{hCG}$ and $\mathrm{hCG} \beta$, which affords them Stokes' radii equivalent to globular molecules of over twice their mass (Butt et al. 1994). In this study we used Sephacryl 200HR size-exclusion matrix, which should resolve molecules with a Stokes' radius of approximately $70 \mathrm{kDa}$ in the middle of its chromatographic range (Kardana et al. 1991). As can be seen from Fig. 1 the major peak of hCG $\beta$ eluted at $\sim 44-55 \mathrm{kDa}$ but a significant late shoulder eluted at $\sim 29 \mathrm{kDa}$. SDS-PAGE was more definitive with two species being resolved at $\sim 32$ and $\sim 64 \mathrm{kDa}$ respectively. With SDS-PAGE these species were only seen together when separated under low stringency conditions in which the sample was only exposed to SDS, non-reducing conditions and not boiled. Heating alone is sufficient to disrupt the $\alpha \beta$ heterodimer of intact hCG releasing free subunits (Gau et al. 1984, Sancken \& Bahner 1995) despite the seatbelt on the $\beta$-subunit holding the $\alpha$-subunit in tight association. When stringent conditions of a disulphide reducing agent ( $\beta$-mercaptoethanol), SDS and heating were employed only the $\sim 32 \mathrm{kDa}$ (monomeric) species could be seen (Fig. 2). The differences in assignment of molecular mass of the species between size-exclusion chromatography and SDSPAGE can be ascribed to the imprecision of these techniques, which can only approximate molecular masses. 
To optimise matrix-assisted ionisation in MALDI, the sample is generally mixed with a roughly equivalent volume of matrix, usually a cinnamic or benzoic acid derivative, dissolved in a mixture of acetonitrile and water $/ 0 \cdot 1 \%$ trifluoroacetic acid; the acidic nature of these conditions is generally considered to be sufficient to disrupt quaternary structures in most circumstances (Hillenkamp et al. 1991, Cohen et al. 1997). Nevertheless, in an earlier study we were able to demonstrate the quaternary structure of the intact hCG heterodimer by MALDI-TOF using an SA matrix (Laidler et al. 1995) and in this current investigation we have observed a mass ion akin to that expected of the $\beta \beta$ homodimer in $\mathrm{SA}$ and sDHB matrices. Of course, such mass spectral data alone are not unequivocal in showing the presence of the $\beta \beta$ homodimer because proteins may form dimers during ionisation. For that reason, we chose also to analyse the preparations of hCG $\beta$ using CHCA, which is a more acidic matrix than SA or sDHB. As the subunits of hCG may be separated under very acidic conditions (Morbeck et al. 1994), it is reasonable to expect the same to be the case for a $\beta \beta$ homodimer. Recent work relating to the proton affinities of commonly used MALDI matrices demonstrated that $\mathrm{CHCA}$ has a lower proton affinity $(183 \pm 2 \mathrm{kcal} / \mathrm{mol})$, and is therefore a stronger acid, than either DHB or SA (both $204 \pm 4 \mathrm{kcal} / \mathrm{mol}$ ) (Burton et al. 1997). On that basis, the peak ascribed to the $\beta \beta$ homodimer, which was observed in the sDHB and SA matrices, would be expected to be attenuated when the CHCA matrix was employed, unless the peak was an artefact due to the ionisation process. Using the CHCA matrix, the peak was so attenuated as for it to be impossible to locate the homodimer. Hence, the contrast in results by MALDI, using different matrices, also supports the presence of the $\beta \beta$ homodimer.

An important factor that influences the stability of the quaternary structure in the heterodimer, and by implication the $\beta \beta$ homodimer, is the large contact surface area between the two interacting subunits; a surface area of approximately $4000 \AA$ is buried by subunit binding (Lapthorn et al. 1994, Wu et al. 1994). The amount of contact surface area of the heterodimer is in contrast to the area of 600-900 ̊ (Novotny et al. 1983, Amit et al. 1986) of an antibody-antigen complex which is completely dissociated by MALDI sample preparation (Nelson et al. 1995).

The quaternary structure of a $\beta \beta$ homodimer could be similar in nature to that of the hCG $\alpha \beta$ heterodimer. The individual subunits are aligned within the heterodimer in a 'head to tail' manner and are stabilised by a structure, nicknamed the seatbelt, formed when residues 90-110 of the $\beta$-subunit wrap around the $\alpha$-subunit before the formation of a last disulphide bond between residues 26 and 110 of the $\beta$-subunit. While formation of the cystine residue $26-110$ prior to subunit contact would appear to hinder extracellular subunit association (Huth et al. 1993), the seatbelt also presents a barrier to heterodimer dissociation; $\mathrm{hCG}$ exists in the circulation at concentrations of $10^{-9}$ to $10^{-11} \mathrm{M}$ despite an equilibrium constant for subunit interaction of approximately $10^{-6}$ M (Strickland \& Puett 1982, Ryan et al. 1988). One may expect a mature $\beta \beta$ homodimer to be more stable than the hCG $\alpha \beta$ heterodimer since its dissociation into hCG $\beta$ monomers could require two seatbelt-like structures to be reduced rather than one. Should this be the case, it is likely that an hCG $\beta \beta$ species intermediate between the monomer and a fully stable hCG $\beta \beta$ homodimer, containing only one seatbelt, also exists. We would expect such an intermediate species to exhibit a stability similar to that of the hCG $\alpha \beta$ heterodimer.

Since biological activities, not mediated through the $\mathrm{LH} / \mathrm{hCG}$ receptor, have been described for both the $\alpha$ - and $\beta$-subunits it is reasonable to suggest that a novel molecular structure may be involved (Blithe et al. 1991, Blithe 1994, Lunardi-Iskandar et al. 1995, Gillott et al. 1996). The experimental data presented here suggest that a $\beta \beta$ homodimer is a possible mediator of the previously reported growth factor activities. The formation of such dimeric molecular species may arise from post-translational events such as glycosylation, which have, in the $\alpha$-subunit, been shown to prevent $\alpha \beta$ heterodimer formation (Blithe et al. 1991). Similar modifications in glycosylation of hCG $\beta$ may favour the formation of the $\beta \beta$ homodimer rather than the $\alpha \beta$ heterodimer. It is not yet known if homodimers form in vivo, but the concentrations analysed here may be comparable with local tissue concentrations. It would, therefore, be feasible to suggest that a proportion of ectopically produced free hCG $\beta$ may exist as a homodimer.

It has not yet been determined whether the $\beta \beta$ homodimer described here is responsible for the growth-promoting activities of hCG $\beta$. However, the demonstration of an hCG $\beta \beta$ homodimer makes it less likely that the responses seen are due to an interaction with the $\mathrm{LH} / \mathrm{hCG}$ receptor and reinforce the view that a novel receptor may be involved. In addition, the predisposition of proteins containing the cystine-knot motif to form homodimers suggests that hCG $\beta$ may possibly form heterodimers with other growth factor subunits, 
thereby creating unique molecules with multifunctional roles.

In conclusion, the results from this investigation support the presence of an hCG $\beta \beta$ homodimer. This unique species may be responsible for the novel biological activities recently attributed to the free $\beta$-subunit, and could play a key role in tumour growth regulation and metastatic control.

\section{ACKNOWLEDGEMENTS}

This work was part funded by grants from the Joint Research Board of St Bartholomew's Hospital, London, the Vandervell Foundation and the Garfield Weston Foundation.

\section{REFERENCES}

Albini A, Paglieri I, Orengo G, Carlone S, Aluigi MG, DeMarchi R, Matteucci C, Mantovani A, Carozzi F, Donini S \& Benelli R 1997 The $\beta$-core fragment of human chorionic gonadotrophin inhibits growth of Kaposi's sarcoma-derived cells and a new immortalised Kaposi's sarcoma cell line. AIDS 11 713-721.

Amit AG, Mariuzza RA, Phillips SEV \& Poljak RJ 1986 Three-dimensional structure of antigen-antibody complex at $2 \cdot 8 \AA$ resolution. Science $233747-753$.

Bell JJ, Canfield RE \& Sciarra JJ 1969 Purification of and characterization of human chorionic gonadotropin. Endocrinology 84 298-307.

Blithe DL 1994 Structure and function of the gonadotropin free alpha molecule of pregnancy. In Glycoprotein Hormones: Structure, Function, Clinical Implications, pp 156-166. Eds JW Lustbader, D Puett \& RW Ruddon. New York: Springer Verlag.

Blithe DL, Richards RG \& Skarulis MC 1991 Free $\alpha$ molecules from pregnancy stimulate secretion of prolactin from human decidual cells: a novel function for free $\alpha$ in pregnancy. Endocrinology 129 2257-2259.

Burton RD, Watson CH, Eyler JR, Lang GL, Powell DH \& Avery MY 1997 Proton affinities of eight matrices used for matrix-assisted laser desorption/ionization. Rapid Communications in Mass Spectrometry 11 443-446.

Butt WR, Chard T \& Iles RK 1994 Hormones of the placenta: hCG and hPL. In Marshalls Physiology of Reproduction, edn 4, vol 3 Pregnancy and Lactation, pp 461-534. Ed. GE Lamming. London: Chapman \& Hall.

Canfield RE, Morgan RJ, Kammerman S, Bell JJ \& Agosto GM 1971 Studies of human chorionic gonadotropin. Recent Progress in Hormone Research 27 121-164.

Cohen LRH, Strupat K \& Hillenkamp F 1997 Analysis of quaternary protein ensembles by matrix assisted laser desorption/ionization mass spectrometry. Fournal of the American Society for Mass Spectrometry 8 1046-1052.

Cuckle HS, Iles RK \& Chard T 1994 Urinary $\beta$-core human chorionic gonadotrophin: a new approach to Down's syndrome screening. Prenatal Diagnosis 14 953-958.

Gau G, Rice A \& Chard T 1984 Increase of hCG levels following heating of serum. Fournal of Obstetrics and Gynecology 5 21-23

Gill PS, Lunardi-Iskandar Y, Louie S, Tulpule A, Zheng, T, Espina BM, Besnier JM, Hermans P, Levine AM, Bryant JL
\& Gallo RC 1996 The effects of preparations of human chorionic gonadotrophin on AIDS-related Kaposi's sarcoma. New England Fournal of Medicine 335 1261-1269.

Gillott DJ, Iles RK \& Chard T 1996 The effects of $\beta$ hCG on the in vitro growth of bladder cancer cells. British Fournal of Cancer 73 323-326.

Greenwood FC, Hunter WM \& Glover JS 1963 The preparation of ${ }^{125} \mathrm{I}$-labelled human growth hormone of high specific radioactivity. Fournal of Biochemistry 89 114-123.

Griffiths SJ, Adams DJ \& Talbot SJ 1997 Ribonuclease inhibits Kaposi's sarcoma. Nature 390568.

Harris PJ 1995 Treatment of Kaposi's sarcoma and other manifestations of AIDS with human chorionic gonadotropin. Lancet 346 118-119.

Heath JK 1993 In Growth Factors, ch 2, pp 15-35. Ed. D Rickwood. Oxford: IRL Press.

Hillenkamp F, Karas M, Beavis RC \& Chait BT 1991 Matrix-assisted laser desorption/ionization mass spectrometry of biopolymers. Analytical Chemistry 63 1193A-1202A.

Huth JR, Perini F, Lockridge O, Bedows E \& Ruddon RW 1993 Protein folding and assembly in vitro parallel intracellular folding and assembly. Fournal of Biological Chemistry 268 16472-16482.

Iles RK 1991 Beta human chorionic gonadotrophin production by bladder tumour cells: incidence, molecular analysis and clinical significance. University of London PhD Thesis p 185.

Iles RK, Lee CL, Oliver RTD \& Chard T 1990 Composition of intact hormone and free subunits in the hCG-like material found in serum and urine of patients with carcinoma of the bladder. Clinical Endocrinology 32 355-364.

Iles RK, Persad R, Trivedi M, Sharma KB, Dickenson A, Smith P \& Chard T 1996 Urinary concentration of hCG and its fragments as a prognostic marker in bladder cancer. British Fournal of Urology 77 61-69.

Kachra Z, Wei-Xing G, Sairam MR \& Antakly T 1997 Low molecular weight components but not dimeric hCG inhibit growth and down-regulate AP-1 transcription factor in Kaposi's sarcoma. Endocrinology 138 4038-4041.

Karas M, Ehring H, Nordhoff E, Stahl B, Strupat K, Hillenkamp F, Grehl M \& Krebs B 1993 Matrix-assisted laser desorption/ionisation mass spectrometry with additives to 2,5-dihydroxybenzoic acid. Organic Mass Spectrometry 28 1476-1481.

Kardana A, Elliott MM, Gawinowicz M-A, Birken S \& Cole LA 1991 The heterogeneity of human chorionic gonadotropin (hCG). I. Characterisation of peptide heterogeneity in 13 individual preparations of hCG. Endocrinology 129 1541-1550.

Kussman M, Nordhoff E, Rahbek-Nielsen H, Haebel S, Rossel-Larsen M, Jakobsen L, Gobom J, Mirgorodskaya E, Kroll-Kristensen A, Palm L \& Roepscorff P 1997 Matrixassisted laser desorption/ionisation mass spectrometry sample preparation techniques for various peptide and protein analytes. Fournal of Mass Spectrometry 32 593-601.

Laemmli UK 1970 Cleavage of structural proteins during the assembly of the head of bacteriophage T4. Nature 227 680-685.

Laidler P, Cowan DA, Hider RC, Keane A \& Kicman AT 1995 Tryptic mapping of human chorionic gonadotrophin by matrix-assisted laser desorption/ionisation mass spectrometry. Rapid Communications in Mass Spectrometry 9 1021-1026.

Lapthorn AJ, Harris DC, Littlejohn A, Lustbader JW, Canfield RE, Machin KJ, Morgan FJ \& Isaacs NW 1994 Crystal structure of hCG. Nature 369 455-461.

Lunardi-Iskandar Y, Bryant JL, Zeman RA, Lam VH, Samaniego F, Besnier JM, Hermans P, Thierry AR, Gill P \& Gallo RC 1995 Tumorigenesis and metastasis of neoplastic 
Kaposi's sarcoma cell line in immunodeficient mice blocked by a human pregnancy hormone. Nature 375 64-68.

Lunardi-Iskandar Y, Bryant JL, Blattner WA, Hung CL, Flamand L, Gill P, Hermans P, Birken S \& Gallo RC 1998 Effects of a urinary factor in women in early pregnancy on HIV-1, SIV and associated disease. Nature Medicine 4 424-434.

Morbeck DE, Madden BJ \& McCormick DJ 1994 Analysis of the microheterogeneity of the glycoprotein chorionic gonadotropin with high-performance capillary electrophoresis. Fournal of Chromatography 680 217-224.

Murray-Rust J, McDonald NQ, Blundell TL, Hosang M, Oefner C, Winkler F \& Bradshaw RA 1993 Topological similarities in TGF-P2, PDGF-BB and NGF define a superfamily of polypeptide growth factors. Structure $\mathbf{1}$ 153-159.

Nelson RW, Krone JR, Bieber AL \& Williams P 1995 Mass spectrometric immunoassay. Analytical Chemistry 67 1153-1158.

Novotny J, Bruccoleri, Newell J, Murphy D, Haber E \& Karplus M 1983 Molecular anatomy of the antibody binding site. Fournal of Biological Chemistry 258 14433-14437.

Peng K-C, Puett D \& Brewer JM 1997 Homodimer formation by the individual subunits of bovine lutropin as determined by sedimentation equilibrium. Fournal of Molecular Endocrinology 18 259-265.

Ryan RJ, Charlesworth MC, McCormick DJ, Milius RP \& Keutmann HT 1988 The glycoprotein hormones: recent studies of structure-function relationships. FASEB Fournal 2 2661-2669.
Sancken U \& Bahner D 1995 The effect of thermal instability of intact human chorionic gonadotropin (ihCG) on the application of its free $\beta$-subunit (free $\beta \mathrm{hCG}$ ) as a serum marker in Down syndrome screening. Prenatal Diagnosis 15 $731-738$

Spencer K, Coombes EJ, Mallard AS \& Milfordward A 1992 Free $\beta$-human choriogonadotropin in Down's syndrome screening: a multicentre study of its role compared with other biochemical markers. Annals of Clinical Biochemistry $29506-518$.

Storring PO, Gaines-Das RE \& Bangham DR 1980 International reference preparation of human chorionic gonadotropin for immunoassay: potency estimates in various bioassay and protein assay systems; and international reference preparations of the $\alpha$ and $\beta$ subunits of human chorionic gonadotropin for immunoassay. Fournal of Endocrinology 84 295-310.

Strickland TW \& Puett D 1982 The kinetic and equilibrium parameters of subunit association and gonadotropin dissociation. Fournal of Biological Chemistry 257 2954-2960.

Sun PD \& Davies DR 1995 The cystine-knot growth-factor superfamily. Annual Review of Biophysics and Biomolecular Structure 24 269-291.

Wu H, Lustbader JW, Liu Y, Canfield RE \& Hendrickson WA 1994 Structure of human chorionic gonadotropin at $2 \cdot 6 \AA$ resolution from MAD analysis of the selenomethionyl protein. Structure $2545-558$.

REVISED MANUSCRIPT RECEIVED 15 September 1998 